\title{
RATOON SUGARCANE YIELD INTEGRATED DRIP-IRRIGATION AND NITROGEN FERTILIZATION
}

\author{
RAÚL A. M. URIBE ${ }^{1}$, GLAUBER J. DE C. GAVA², JOÃO C. C. SAAD ${ }^{3}$, ORIEL T. \\ KÖLLN ${ }^{4}$
}

\begin{abstract}
The aim of this study was to compare the use of water and nitrogen on ratoon sugarcane during irrigated and rain-fed conditions, and to assess the production potential of stalks and sugar with different rates of $\mathrm{N}$-fertilizer on the subsurface drip-irrigated management. The experimental design was a randomized block with four replications for each experiment and treatments: (T1) irrigated, $0 \mathrm{~kg} \mathrm{~N} \mathrm{ha}^{-1}$; (T2) irrigated, $70 \mathrm{~kg} \mathrm{~N}^{-1}$; (T3) irrigated, $140 \mathrm{~kg} \mathrm{~N} \mathrm{ha}^{-1}$; (T4) irrigated, $210 \mathrm{~kg} \mathrm{~N} \mathrm{ha}^{-1}$; (T5) not irrigated, $0 \mathrm{~kg} \mathrm{~N} \mathrm{ha}^{-1}$, and (T6) not irrigated, $140 \mathrm{~kg} \mathrm{~N} \mathrm{ha}^{-1}$. Biometric, technological, dry matter and yield variables were analyzed among the treatments. The irrigation system together with the application of $\mathrm{N}$-fertilizer at $140 \mathrm{~kg} \mathrm{ha}^{-1}$ presented significant differences in dry matter accumulation of shoots, and for the production of stalks and sugar, respectively 94, 105 and 106\%, higher when compared to the not irrigated, without N-fertilizer (T5). There was a positive and synergistic effect of irrigation with $\mathrm{N}$-fertilizer on the productivity of stalks and sugar. Ratoon sugarcane irrigated with subsurface dripping had the highest yield (22Mg ha ${ }^{-1}$ of sugar) with the dosage of $140 \mathrm{~kg} \mathrm{ha}^{-1} \mathrm{~N}$.
\end{abstract}

KEYWORDS: fertigation, nitrogen, water stress, Sacharum spp.

\section{PRODUTIVIDADE DE SOQUEIRA DE CANA-DE-AÇÚCAR INTEGRADA À IRRIGAÇÃO POR GOTEJAMENTO E À FERTILIZAÇÃO NITROGENADA}

RESUMO: Objetivou-se neste trabalho comparar a utilização de água e de nitrogênio em soqueira de cana-de-açúcar nos manejos irrigado e de sequeiro, e verificar o potencial de produção de colmos e de açúcar com diferentes doses de $\mathrm{N}$-fertilizante, em manejo irrigado por gotejamento subsuperficial. O delineamento experimental utilizado foi o de blocos ao acaso, com seis tratamentos e quatro repetições, sendo os tratamentos: (T1) irrigado, $0 \mathrm{~kg} \mathrm{~N} \mathrm{ha}^{-1}$; (T2) irrigado, $70 \mathrm{~kg} \mathrm{~N} \mathrm{ha}^{-1}$; (T3) irrigado, $140 \mathrm{~kg} \mathrm{~N} \mathrm{ha}^{-1}$; (T4) irrigado, $210 \mathrm{~kg} \mathrm{~N} \mathrm{ha}^{-1}$; (T5) manejo de sequeiro, $0 \mathrm{~kg} \mathrm{~N} \mathrm{ha}{ }^{-1}$; (T6) manejo de sequeiro, $140 \mathrm{~kg} \mathrm{~N} \mathrm{ha}^{-1}$. Foram realizadas análises de variáveis biométricas, tecnológicas, de matéria seca e de produtividade entre os tratamentos. O sistema de irrigação, em conjunto com a aplicação de $\mathrm{N}$-fertilizante na dose de $140 \mathrm{~kg} \mathrm{ha}^{-1}$ (tratamento T3), gerou diferenças significativas para acúmulo de matéria seca da parte aérea e para produtividade de colmos e de açúcar, sendo, respectivamente, 94; 105 e 106\% superiores ao tratamento de sequeiro, sem dose de N (T5). Verificou-se efeito positivo e sinérgico da irrigação com N-fertilizante na produtividade de colmos e de açúcar. A soqueira de cana-de-açúcar irrigada por gotejamento subsuperficial obteve a máxima produtividade (22 $\mathrm{Mg} \mathrm{ha}^{-1}$ de açúcar) com a dose de $140 \mathrm{~kg} \mathrm{ha}^{-1}$ de N.

PALAVRAS-CHAVE: fertirrigação, nitrogênio, estresse hídrico, Sacharum spp.

\footnotetext{
${ }^{1}$ Professor Doutor da Universidade Sagrado Coração, Bauru.

${ }^{2}$ Pesquisador Científico da APTA, Pólo Regional do Centro Oeste, Jaú.

${ }^{3}$ Professor Assistente Doutor da FCA UNESP, Botucatu.

${ }^{4}$ Engenheiro Agrônomo do CTBE, Campinas.

Recebido pelo Conselho Editorial em: 21-3-2013

Aprovado pelo Conselho Editorial em: 2-8-2013
} 


\section{INTRODUCTION}

The increasing world demand for sugar and energy (ethanol and bioelectricity), has led to the rise in the cost of land in areas that traditionally produced sugarcane and the expansion of sugarcane cultivation to regions with higher water deficit (GONÇALVEZ, 2009). Thus, it is assumed that the use of irrigation technology will increase their importance, and its focus will be: raising crop productivity, especially in traditional growing areas, and maintaining sustainability of new agricultural businesses, installed in the areas of greatest water deficit (DALRI \& CRUZ, 2008; SILVA et al., 2009; GAVA et al., 2011).

The productive potential of irrigated sugarcane depends on a number of factors, including: the amount of water and fertilizers applied (WIEDNFELD, 2000; SILVA et al., 2009), the system and irrigation management, the cultivar, cutting age and the type of soil and climate (CARR \& KNOX, 2011).

Drip-irrigation, when properly employed, can increase the efficiency of use of water and nutrients for the plant, including nitrogen, resulting in increased yield of stalks and sugar (NG KEE KWONG et al., 1999; GAVA et al., 2010).

Regarding the interaction between nitrogen fertilizers and irrigation for sugarcane, THORBURN et al. (2003) studied the importance of fertigation with $\mathrm{N}$ in four production cycles, and found that the yield of stalks and sugar responded to $\mathrm{N}$ fertilization through irrigation. WIEDNFELD (1995) also researched the effect of irrigation and fertilization with N-fertilizer on the quality and productivity of sugarcane and concluded that the yield of stalks and sugar responded linearly to nitrogen fertilization, especially in stubbles, and higher responses are associated with higher levels of irrigation. NG KEE KWONG et al. (1999) found that the use of subsurface dripirrigation systems with different dosages of nitrogen, allowed the reduction by $30 \%$ of the values of $\mathrm{N}$-fertilization without significant drop in productivity of stalks as a result of better distribution of fertilizer throughout the development of culture. RAVIKUMAR et al. (2011) using the HYDRUS$2 \mathrm{D}$ software determined that an efficient planning of drip-irrigation can reduce up to $30 \%$ in the use of urea as a source of $\mathrm{N}$.

Therefore, the objectives of this study were: i) to compare the use of water and N-fertilizer in ratoon cane in not irrigated and irrigated by subsurface drip systems and ii) to determine the production potential of ratoon sugarcane with different dosages of $\mathrm{N}$-fertilizer in irrigated subsurface drip management.

\section{MATERIAL AND METHODS}

The experiment was installed on September $26^{\text {th }}, 2008$ and lasted for 365 days, at the Unit of Research and Development of Jaú (APTA, Pólo Regional Centro Oeste), in São Paulo State, Brazil, located at $22^{\circ} 17^{\prime} \mathrm{S}$ latitude, $48^{\circ} 34^{\prime} \mathrm{W}$ longitude and with an average altitude of $580 \mathrm{~m}$. The soil was classified as Oxisol, which layer 0-25cm presented: $\mathrm{pH}\left(\mathrm{CaCl}_{2}\right) 5.2$; $\mathrm{P}$ (resin) $19.0 \mathrm{mg} \mathrm{dm}^{-3}$; $\mathrm{K}$ $0.9 \mathrm{mmol}_{\mathrm{C}} \mathrm{dm}^{-3}$, Ca $27.0 \mathrm{mmol}_{\mathrm{C}} \mathrm{dm}^{-3}, \mathrm{Mg}^{2} .0 \mathrm{mmol}_{\mathrm{c}} \mathrm{dm}^{-3}$; CTC $105.0 \mathrm{mmol}_{\mathrm{C}} \mathrm{dm}^{-3}$; V (\%) 66; and composition of sand, silt and clay of $660,70,270 \mathrm{~g} \mathrm{~kg}^{-1}$, respectively.

The third production cycle (second ratoon) of cultivar SP80-3280 was studied in this research. The experimental design was of randomized blocks with six treatments and four replications, which treatments are described below: (T1) irrigated without nitrogen (N); (T2) irrigated with a dosage of $70 \mathrm{~kg} \mathrm{ha}^{-1}$ of $\mathrm{N}$; (T3) irrigated with $140 \mathrm{~kg} \mathrm{ha}^{-1}$ of N; (T4) irrigated with a dosage of $210 \mathrm{~kg} \mathrm{ha}^{-1}$ of $\mathrm{N}$; (T5) not irrigated with no dosage of N; and (T6) not irrigated with $140 \mathrm{~kg} \mathrm{ha}^{-1}$ of $\mathrm{N}$. All dosages of $\mathrm{N}$ were applied as urea.

The plots were constituted of five rows of $30 \mathrm{~m}$ (plot area of $270 \mathrm{~m}^{2}$ ), with an usable area composed of three central rows of sugarcane, with less than $2.5 \mathrm{~m}$ in length at each end of the plot of the surround the area, totaling $25 \mathrm{~m}$ (plot usable area of $135 \mathrm{~m}^{2}$ ). In all treatments, double line plantation was used ("W" style plantation), spaced $1.80 \mathrm{~m}$ between double rows. For irrigated 
treatments, dripper tubes were buried $25 \mathrm{~cm}$ deep from the soil surface, in the middle of the double line. The dripper tube used was DRIPNET PC $22135 \mathrm{FL}$ with a flow of $1.0 \mathrm{~L} \mathrm{~h}^{-1}$ and a operating pressure of $190 \mathrm{kPa}$ with emitters spaced $0.5 \mathrm{~m}$ from each other.

The frequency of irrigation was performed by counting the supply of water to the soil, by precipitation (P) and atmospheric demand, by evapotranspiration of sugarcane (ETC), with a maximum storage level or available water capacity of $100 \mathrm{~mm}$, so an estimate of the decennial water balance was made and water deficit (DEF) was calculated during the growing season of 2008-2009 (Figures 1A and 1B). The rainfall for the period was $1,740 \mathrm{~mm}$ and the total water depth applied with irrigation was $293 \mathrm{~mm}$. Irrigation management was carried out taking into account the ETC replacing $100 \%$ of evapotranspired depth according to the PENMAN-MONTEITH and also for tensiometer sets installed in the experiment at 20, 40 and $60 \mathrm{~cm}$ depth.
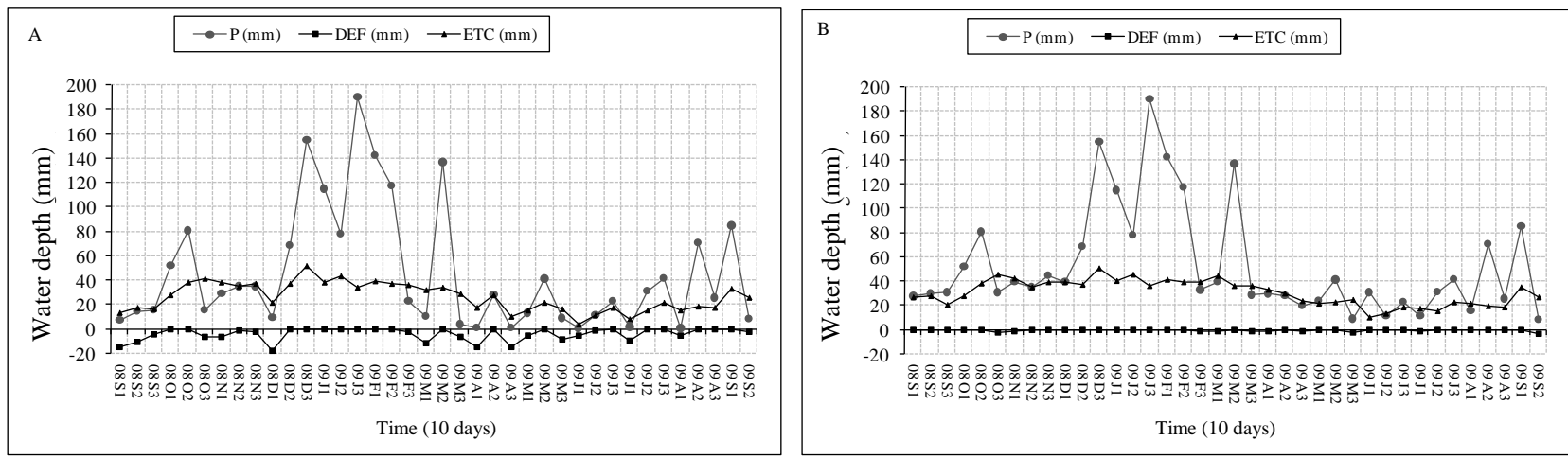

FIGURE 1. Water balance of sugarcane under not irrigated conditions (A) and irrigated (B) in the agricultural year of 2008 - 2009.

All treatments received a dosage of $150 \mathrm{~kg} \mathrm{ha}^{-1}$ of $\mathrm{K}_{2} \mathrm{O}$ in the form of potassium chloride. The application of $\mathrm{N}$ and $\mathrm{K}_{2} \mathrm{O}$ in the irrigated treatments was made by fertigation held throughout the crop growth, and in not irrigated treatments (rain-fed management) 30 days after the ratoon cut (Figure 2).

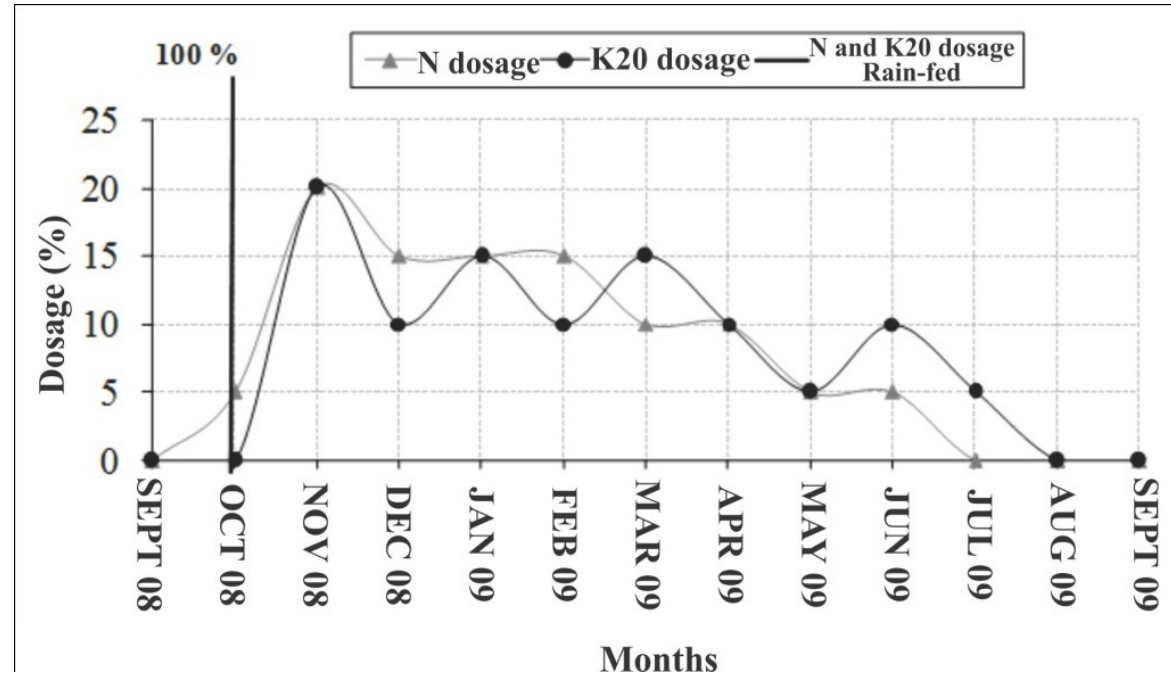

FIGURE 2. Percentage distribution of $\mathrm{N}$ and $\mathrm{K}_{2} \mathrm{O}$ irrigated by dripping and not irrigated in ratoon sugarcane.

At the end of the crop cycle (at 365 days after the ratoon cut), evaluations were performed to quantify the number of tillers per meter, the diameter of stalks and plant height (from ground to first leaf (leaf +1 ), with fully expanded ligule). These measurements were made with a measuring tape, from each plot at different treatments. 
To estimate the dry matter production of shoots of sugarcane, 2 meters were harvested by separating samples of dried leaves, top of cane (the top of stalks and green leaves) and stalks. All of this material was ground separately by a forage harvester. After grinding and mixing each wet sample, subsamples were removed and subsequently they were dried in a forced ventilated greenhouse, at a temperature of $65^{\circ} \mathrm{C}$ until their mass remained constant. With these results the average production of dry matter of shoots of sugarcane, top of cane and dry leaves (TC+DL) and stalks, in $\mathrm{Mg} \mathrm{ha}^{-1}$, considering that a hectare had 5,556 meters of sugarcane, was calculated.

Before the final harvest, ten stalks in each plot were sampled for the performance of technological analysis, as CONSECANA (2006). Productivity in stalks per hectare (HSP) was obtained through the proportional relationship with the area of each plot, considering 5,556 meters of sugarcane per hectare. The sugar yield per hectare was calculated as the product of HSP and sugar \% (sucrose content).

The results obtained were subjected to analysis of variance using the $\mathrm{F}$ test at $5 \%$, and for significant variations, Tukey's significance test $(\mathrm{p}<0.05)$ was carried out for comparison between treatments: T1, T3, T5 and T6 (water and nitrogen in sugarcane); and regression analysis to the following treatments: T1, T2, T3 and T4 (sugarcane irrigated with subsurface dripping, with different $\mathrm{N}$-fertilizer rates).

\section{RESULTS AND DISCUSSION}

Regarding the plant height, stalk diameter and number of tillers per meter, it was observed that there was no statistically significant difference between treatments (Table 1). These results differ from those obtained by DALRI \& CRUZ (2008), who observed no statistically significant differences between treatments: irrigated and not irrigated with different rates of fertilization for the variables plant height stalk diameter and number of tillers per meter.

The number of tillers per meter showed high value when compared with the results of ALMEIDA et al. (2008), who reported average values of 13, 11, 9, 8 and 11 tillers per meter for the respective cultivars: RB92579, RB93509, SP79-1011, RB931530. The increased number of tillers per meter, found in this study, can be explained by the "W" tillage system, which has double rows, thus a greater number of plants per meter.

Although no statistically significant differences were observed between treatments for biometric variables, probably due to the high coefficient of variation (Table 1), there was a positive trend in the response of sugarcane irrigation, mainly for the height of plants and number of tillers per meter. In fact, SILVA et al. (2008) found a positive correlation between these variables and productivity, showing that the increase in these two variables caused by the ideal supply of water directly influenced the production of stalks.

TABLE 1. Effect of nitrogen fertilization and irrigation on biometric parameters of sugarcane.

\begin{tabular}{lccc}
\hline Managements & $\begin{array}{c}\text { Height of the } \\
\text { plants } \\
------(\mathrm{cm})-----\end{array}$ & $\begin{array}{c}\text { Diameter of the } \\
\text { stalks } \\
--(\mathrm{mm})--\end{array}$ & $\begin{array}{c}\text { Number of tillers } \\
--\left(\mathrm{m}^{-1}\right)--\end{array}$ \\
\hline (T5) Not irrigated-0 kg ha ${ }^{-1} \mathrm{~N}$ & $170.05 \mathrm{a}$ & $25 \mathrm{a}$ & $12 \mathrm{a}$ \\
(T1) Irrigated-0kg ha ${ }^{-1} \mathrm{~N}$ & $162.52 \mathrm{a}$ & $25 \mathrm{a}$ & $18 \mathrm{a}$ \\
(T6) Not irrigated-140kg ha $^{-1} \mathrm{~N}$ & $178.16 \mathrm{a}$ & $26 \mathrm{a}$ & $16 \mathrm{a}$ \\
(T3) Irrigated-140kg ha $\mathrm{N}^{-1} \mathrm{~N}$ & $184.36 \mathrm{a}$ & $27 \mathrm{a}$ & $19 \mathrm{a}$ \\
\hline & 16.03 & 11 & 11 \\
\hline
\end{tabular}

*Measurements followed by different letters differ significantly by the Tukey’s test $\mathrm{p}<0.05$. *CV: coefficient of variation.

It was found that there was no statistically significant difference in the evaluated technological parameters, demonstrating that the system of subsurface drip-irrigation did not alter 
the quality of sugarcane. The results obtained by DALRI \& CRUZ (2008) and GAVA et al. (2011) corroborate with these results (Table 2).

TABLE 2. Effect of nitrogen fertilization and irrigation on technological parameters of sugarcane.

\begin{tabular}{|c|c|c|c|c|}
\hline Managements & Sugar & Fiber & Brix & Pol \\
\hline (T5) Not irrigated-0 kg ha ${ }^{-1} \mathrm{~N}$ & $16.66 \mathrm{a}$ & $13.01 \mathrm{a}$ & 21.37 a & $20.02 \mathrm{a}$ \\
\hline (T1) Irrigated-0 $\mathrm{kg} \mathrm{ha}^{-1} \mathrm{~N}$ & $17.25 \mathrm{a}$ & $13.65 \mathrm{a}$ & $22.36 \mathrm{a}$ & $20.97 \mathrm{a}$ \\
\hline (T6) Not irrigated-140kg ha ${ }^{-1} \mathrm{~N}$ & $16.83 \mathrm{a}$ & $12.95 \mathrm{a}$ & $21.74 \mathrm{a}$ & $20.21 \mathrm{a}$ \\
\hline (T3) Irrigated-140kg ha ${ }^{-1} \mathrm{~N}$ & $16.29 \mathrm{a}$ & $13.60 \mathrm{a}$ & $21.44 \mathrm{a}$ & $19.79 \mathrm{a}$ \\
\hline$* \mathrm{CV}(\%)$ & 3.23 & 3.01 & 2.25 & 3.06 \\
\hline
\end{tabular}

*Measurements followed by different letters differ significantly by the Tukey's test $\mathrm{p}<0.05$. ${ }^{*} \mathrm{CV}$ : coefficient of variation.

It is found significant effect of irrigation and nitrogen fertilizer for the accumulation of dry mass of stalks, top of cane and dry leaves (TC+DL) and shoots of sugarcane, as well as the productivity of stalks (HSP) and sugar for the different managements compared (Table 3).

Irrigation plays a key role in the growth and biomass production. FARIAS et al. (2008) studied the cultivar SP 79-1011 in the North Paraiba region, researched the efficiency of water use and reported values of 31.13 and $88.10 \mathrm{Mg} \mathrm{ha}^{-1}$ for the rain-fed and irrigated with a water depth of $100 \%$ of the crop evapotranspiration (ETC) managements, respectively. The previous value of HSP was $31.13 \mathrm{Mg} \mathrm{ha}{ }^{-1}$ and differs substantially from that found in this study $\left(64.7 \mathrm{Mg} \mathrm{ha}^{-1}\right)$ for not irrigate sugarcane with $0 \mathrm{~kg} \mathrm{ha}^{-1}$ of $\mathrm{N}$. One possible explanation may be the residual effect of nitrogen fertilization in previous seasons (the entire area was fertilized with a rate of $70 \mathrm{~kg} \mathrm{ha}^{-1}$ of $\mathrm{N}$ during the previous crop). AMBROSANO et al. (2011) studied the residual effect of mineral fertilization with ammonium sulfate $\left(70 \mathrm{~kg} \mathrm{ha}^{-1}\right.$ of $\left.\mathrm{N}\right)$ and green manure with Crotalaria juncea $\mathrm{L}$. (195.8 kg ha $\mathrm{kg}^{-1} \mathrm{~N}$ ) and showed yields (HSP) of $64.7 \mathrm{Mg} \mathrm{ha}^{-1}$ for the crop one year after fertilization, thus underscoring the residual effect of the first fertilization.

TABLE 3. Dry matter accumulation of stalks, top of cane and dry leaves (TC+DL), sugarcane shoots (Dry shoots), stalks and sugar productivity, with and without N-fertilizer in irrigated and not irrigated managements.

\begin{tabular}{|c|c|c|c|c|c|}
\hline Managements & $\begin{array}{c}\text { Dry } \\
\text { stalks }\end{array}$ & $\mathrm{TC}+\mathrm{DL}$ & Dry shoots & Stalks & Sugar \\
\hline & & & $\left.\mathrm{Mg} \mathrm{ha}^{-1}\right)-$ & & \\
\hline (T5) Not irrigated-0kg ha ${ }^{-1} \mathrm{~N}$ & $17.6 \mathrm{c}$ & $14.2 \mathrm{C}$ & $31.8 \mathrm{c}$ & $64.7 \mathrm{c}$ & $10.8 \mathrm{c}$ \\
\hline (T1) Irrigated-0 kg ha ${ }^{-1} \mathrm{~N}$ & $24.1 \mathrm{~b}$ & $17.4 \mathrm{~b}$ & $41.4 \mathrm{~b}$ & $83.6 \mathrm{~b}$ & $14.4 \mathrm{~b}$ \\
\hline (T6) Not irrigated-140 $\mathrm{kg} \mathrm{ha}^{-1} \mathrm{~N}$ & $26.9 \mathrm{~b}$ & $17.9 \mathrm{~b}$ & $44.8 \mathrm{~b}$ & $91.3 \mathrm{~b}$ & $15.3 \mathrm{~b}$ \\
\hline (T3) Irrigated $-140 \mathrm{~kg} \mathrm{ha}^{-1} \mathrm{~N}$ & 39.9 a & 21.9a & $61.8 \mathrm{a}$ & $132.8 \mathrm{a}$ & $22.3 \mathrm{a}$ \\
\hline CV (\%) & 14.8 & 7.0 & 15.0 & 14.1 & 10.5 \\
\hline
\end{tabular}

*Measurements followed by different letters differ significantly by the Tukey's test $\mathrm{p}<0.05$. *CV: coefficient of variation.

The difference between $\mathrm{T} 1$ and $\mathrm{T} 5$ managements regarding HSP can be explained by the greater efficiency of the irrigation system (subsurface dripping) compared to not irrigate sugarcane, even with no rainfall amounts sufficient to cause severe deficits for the period studied (Figure 1).

In drip-irrigated treatment with $140 \mathrm{~kg} \mathrm{ha}^{-1}$ of $\mathrm{N}$, the increase in stalks productivity was $100 \%$ when compared to not irrigated management with dosage of $0 \mathrm{~kg} \mathrm{ha}^{-1}$ of $\mathrm{N}$ (T5), and $50 \%$ compared to treatments considered equal by the Tukey's test (irrigated with dosage of $0 \mathrm{~kg} \mathrm{ha}^{-1}$ of $\mathrm{N}$ and not irrigated with $140 \mathrm{~kg} \mathrm{ha}^{-1}$ of N). THORBURN et al. (2003) obtained a yield of $65 \mathrm{Mg} \mathrm{ha}^{-1}$ and $52 \mathrm{Mg} \mathrm{ha}^{-1}$ (25\% lower), comparing the managements of: drip-irrigation and not irrigated, dosage of $140 \mathrm{~kg} \mathrm{ha}^{-1}$ of N. The same was observed in Mauritius by NG KEE KWONG \& DEVILLE (1994) to evaluate fertigation systems with $\mathrm{N}$ in sugarcane, noting that when comparing the control 
(treatment without irrigation and without $\mathrm{N}$-fertilizer) with irrigated treatments with $\mathrm{N}$, the increase in productivity was $71 \%$, thus demonstrating the importance of proper distribution of nitrogen supply throughout the crop cycle.

DALRI \& CRUZ (2008) using the cultivar RB 72454 in a Oxisol of Botucatu, São Paulo, observed the interaction between nitrogen and amount of water applied in the second ratoon crop of sugarcane. The researchers found that stalks yield was 100.98 and $138.07 \mathrm{Mg} \mathrm{ha}^{-1}$ in not irrigated and irrigated systems fertilized with $150 \mathrm{~kg} \mathrm{ha}^{-1}$ of $\mathrm{N}$-fertilizer, respectively, resulting in an increase of $36.73 \%$. This value is close to that found in the present study (45\%).

From the results obtained in the scientific literature and verified in Table 3, it can be inferred that there is a synergistic effect of nitrogen fertilizer applied in conjunction with irrigation water, resulting in significantly increased productivity of ratoon sugarcane.

Sugar, and HSP, also responded positively to the application of water and nitrogen, and it was higher in the treatment T3 at 45, 54 and 106\% compared with only fertilized treatment T6, only irrigated (T1) and the control (T5), respectively. This result has a similar trend to that found by WIEDENFELD (1995), who obtained increases of 39\% in fertigated sugarcane with $168 \mathrm{~kg} \mathrm{ha}^{-1}$ of N. It is noteworthy that even if sugar (\%) was lower with an increasing of the dosage of N (Table 5) Sugar still had a positive response by the considerable increase in the values of yield stalks (HSP) with supplementation of water and nitrogen.

The availability of water in the soil is an extremely important variable because it affects not only the development of sugarcane, but also the diversity, survival, movement and activity of soil microorganisms (BLUM et al., 2012). This behavior can be verified by comparing treatments: T1 (irrigated without nitrogen), with T6 (not irrigated with $140 \mathrm{~kg} \mathrm{ha}^{-1}$ of $\mathrm{N}$ ) that did not differ statistically, probably due to the increased rate of mineralization of soil organic matter in T1, which supplied the demand of $\mathrm{N}$ of the plant, resulting in an increase in productivity. Soil moisture has important effects on the mineralization of organic $\mathrm{N}$, since it directly determines the availability of water for the activity and survival of microorganisms, thereby increasing the levels of mineralized nitrogen (COOK \& ORCHARD, 2008 and STUTTER et al., 2013).

There was a significant effect of nitrogen fertilization for variable height of the plants (Table 4). WIEDENFELD \& ENCISO (2008) found similar quadratic response to the application of N via subsurface irrigation system for the variable plant height. The researchers found values of 165 and $170 \mathrm{~cm}$ for dosages of 60 and $140 \mathrm{~kg} \mathrm{ha}^{-1}$ of N, respectively.

TABLE 4. Number of tillers, height and diameter of stalks in function of dosages of N-fertilizer applied in drip-irrigated sugarcane.

\begin{tabular}{cccc}
\hline $\begin{array}{c}\text { Managements } \\
\mathrm{kg} \mathrm{ha}^{-1} \text { of N }\end{array}$ & $\begin{array}{c}\text { Plant height } \\
-----(\mathrm{cm})----\end{array}$ & $\begin{array}{c}\text { Diameter of stalks } \\
---(\mathrm{mm})---\end{array}$ & $\begin{array}{c}\text { Number of tillers } \\
----\left(\mathrm{m}^{-1}\right)----\end{array}$ \\
\hline 0 & 162.52 & 25 & 18 \\
70 & 162.76 & 26 & 18 \\
140 & 184.36 & 27 & 19 \\
210 & 212.03 & 28 & 18 \\
\hline Average & 180.42 & 26 & 10 \\
CV (\%) & 15.66 & 9 & $0.00 \mathrm{~ns}$ \\
\hline F - reg. 1st & $8.98^{*}$ & $2.96 \mathrm{~ns}$ & - \\
degree & 0.39 & - & $0.07 \mathrm{~ns}$ \\
$\mathrm{R}^{2}$ & $5.14^{*}$ & $0.00 \mathrm{~ns}$ & - \\
\hline F - reg. 2nd & 0.44 & - & \\
degree & $\mathrm{R}^{2}$ & &
\end{tabular}

* significant by $\mathrm{F}$ test $\mathrm{p}<0.05$ and ns: nonsignificant. $\mathrm{R}^{2}$ : coefficient of determination. 
The effect of nitrogen fertilization was studied by WIEDENFELD (1995), who found that plant growth was dependent on the amount of $\mathrm{N}$ applied, since it forms the chlorophyll molecule, responsible for the photosynthetic rate and the accumulation of carbon, generating the cell growth.

The increase of nitrogen dosage did not affect the fiber and Brix contents of the stalks, but decreased the sugar content of the raw material (Table 5). A high $\mathrm{N}$ supply causes sugarcane to grow and have more ability to produce carbohydrate (biomass), but keeping the higher $\mathrm{N}$ rates, may continue to stimulate vegetative growth, reducing sugar concentration in the stalk (MUCHOW et al. 1996). FRANCO et al. (2011) observed an increase in biomass production of the area up to $50 \%$ with dosages of $120 \mathrm{~kg} \mathrm{ha}^{-1}$ of nitrogen. MUCHOW et al. (1996), working with different dosages of nitrogen in rain-fed systems, found that the values of sugar decreased from 16.1 to $13.1 \%$ when the dosage of nitrogen increased from 56 to $268 \mathrm{~kg} \mathrm{ha}^{-1}$.

The sugar productivity is the result percentage of sugar (\%) and the amount of stalks. In this study it can be seen that the increase of $\mathrm{N}$ dosages of 0 to $210 \mathrm{~kg} \mathrm{ha}^{-1}$ caused a reduction of $1 \%$ in percentage of sugar (Table 5). However, even with the fall of sugar percentage, productivity of sugar was increased from 14 to $22 \mathrm{Mg} \mathrm{ha}^{-1}$ (Table 6); it occurs because the stalks production far exceeded the fall of sugar percentage (Tables 5 and 6). Similar to the results of this study were obtained by WIEDENFELD, (1995). With the results in Tables 2 and 5, it is possible to verify that the parameters related to the quality of sugarcane are more influenced by nitrogen fertilization than by the drip-irrigation system (water availability).

TABLE 5. Technological variables of stalks in function of dosages of $\mathrm{N}$-fertilizer applied in dripirrigated sugarcane.

\begin{tabular}{|c|c|c|c|c|}
\hline $\begin{array}{l}\text { Managements of } \\
\mathrm{N} \mathrm{kg} \mathrm{ha}^{-1}\end{array}$ & $\begin{array}{r}\text { Sugar } \\
--\end{array}$ & Fiber & Brix & Pol \\
\hline 0 & 17.3 & 13.7 & 22.4 & 21.0 \\
\hline 70 & 17.1 & 13.1 & 22.3 & 20.6 \\
\hline 140 & 16.3 & 13.6 & 21.4 & 19.8 \\
\hline 210 & 16.6 & 13.6 & 22.0 & 20.1 \\
\hline Average & 16.8 & 13.5 & 22.0 & 20.37 \\
\hline CV (\%) & 2.90 & 5.41 & 1.97 & 2.83 \\
\hline F - reg. 1st degree & $6.50 *$ & $0.05 \mathrm{~ns}$ & $3.98 \mathrm{~ns}$ & $6.51 *$ \\
\hline $\mathrm{R}^{2}$ & 0.32 & - & - & 0.32 \\
\hline F - reg. 2nd degree & $0.54 \mathrm{~ns}$ & $0.63 \mathrm{~ns}$ & $2.10 \mathrm{~ns}$ & $3.88 *$ \\
\hline $\mathrm{R}^{2}$ & - & - & - & 0.37 \\
\hline
\end{tabular}

* significant by $\mathrm{F}$ test $\mathrm{p}<0.05$ and ns: nonsignificant. $\mathrm{R}^{2}$ : coefficient of determination.

Regarding the dosages of $\mathrm{N}$ studied, in the subsurface drip-irrigation system, it is possible to verify that there was a significant response in the accumulation of dry mass of stalks, top cane and dry leaves (TC+DL), in shoots of sugarcane, and in the productivity of stalks and sugar, for the application of different rates of $\mathrm{N}$ fertilizer (Table 6). Similar to the results of this study were obtained in literature by WIEDENFELD (1995); NG KEE KWONG et al. (1999); THORBURN, et al. (2003); DALRI \& CRUZ (2008); WIEDENFELD \& ENCISO (2008) and SILVA et al. (2009). 
TABLE 6. Dry matter accumulation of stalks, top of cane and dry leaves (TC+DL), sugarcane shoots (Dry shoots), stalks (HSP) and sugar productivity in function of N-fertilizer dosages applied in drip-irrigated sugarcane.

\begin{tabular}{cccccc}
\hline $\begin{array}{c}\text { Managements of } \\
\mathrm{N} \mathrm{kg} \mathrm{ha}^{-1}\end{array}$ & Dry stalks & TC+DL & Dry shoots & Stalks & Sugar \\
\hline 0 & 24.1 & 17.4 & 41.4 & 83.6 & 14.4 \\
70 & 25.7 & 21.5 & 49.3 & 97.5 & 16.7 \\
140 & 39.9 & 21.9 & 61.8 & 132.8 & 22.3 \\
210 & 39.8 & 24.2 & 64.1 & 130.4 & 21.6 \\
Average & 32.4 & 21.2 & 54.2 & 111.1 & 18.8 \\
\hline CV (\%) & 11.5 & 14.0 & 12.6 & 15.4 & 5.2 \\
\hline F - reg. 1st & $37.92^{*}$ & $3.45 \mathrm{~ns}$ & $23.84^{*}$ & $30.7 *$ & $25.5^{*}$ \\
degree & 0.73 & 0.20 & 0.63 & 0.69 & 0.65 \\
$\mathrm{R}^{2}$ & $1.3 *$ & $1.68^{*}$ & $12.00^{*}$ & $16.4 *$ & $14.26 *$ \\
\hline F - reg. 2nd & 0.75 & 0.21 & 0.65 & 0.72 & 0.69 \\
degree & $\mathrm{R}^{2}$ & 0.05 &
\end{tabular}

* significant by $\mathrm{F}$ test $\mathrm{p}<0.05$ and ns: nonsignificant. $\mathrm{R}^{2}$ : coefficient of determination.

Nitrogen fertilization associated with the drip-irrigation system increased the production of dry mass of sugarcane, with a consequent increase yield of stalks and sugar. With the use of the subsurface drip-irrigation system, the crop response to $\mathrm{N}$ was intensified (WIEDENFELD, 1995; WIEDENFELD \& ENCISO, 2008), due to decreased fluid restriction and also by raising the concentration of $\mathrm{N}^{-\mathrm{NH}_{4}}{ }^{+}$and $\mathrm{N}_{-} \mathrm{NO}_{3}{ }^{-}$in the soil solution mainly in the region of wet bulb (THORBURN, et al., 2003), over the period of growth and development of sugarcane. Furthermore, the importance of nitrogen for sugarcane refers to the fact that the plant has C4 metabolism, characterized by a high photosynthetic net rate, and a high efficiency of utilization of solar energy and nitrogen, thus it is very effective in dry matter production (FRANCO et al., 2010). These characteristics are directly related to the increase of dry matter until the range that even with an increasing $\mathrm{N}$ supply no responses are observed, also called luxury consumption (MUCHOW et al., 1996).

There is much controversy about the nitrogen fertilization on sugarcane, particularly when evaluating different variables that may be involved as a source of $\mathrm{N}$-fertilizer, old sugarcane plantation (sugarcane plant or ratoon) and water availability, among others (WIEDENFELD \& ENCISO, 2008; FRANCO et al., 2011). In Brazil, some research has been conducted reporting positive results with greater than $200 \mathrm{~kg} \mathrm{ha}^{-1}$ of $\mathrm{N}$-fertilizer (DALRI \& CRUZ, 2008) dosages. In this experiment (Table 6) it was found that $140 \mathrm{~kg} \mathrm{ha}^{-1}$ of $\mathrm{N}$ reached the maximum production of stalks (133Mg ha $\left.{ }^{-1}\right)$ and sugar $\left(22 \mathrm{Mg} \mathrm{ha}^{-1}\right)$ and the response was similar the dosage of $210 \mathrm{~kg} \mathrm{ha}^{-1}$ of N.

\section{CONCLUSIONS}

There was a synergistic effect of the combined application of nitrogen fertilizer and water through drip-irrigation on production of sugarcane.

The subsurface drip-irrigation did not alter the technical characteristics of sugarcane (cultivar SP80-3280).

The ratoon sugarcane reached maximum productivity at $140 \mathrm{~kg} \mathrm{ha}^{-1}$ of $\mathrm{N}$, using a subsurface drip-irrigation system. 


\section{ACKNOWLEDGEMENTS}

Raízen group, Unit Barra Bonita, to Netafim, and the Farmers Association of Sugarcane Jaú (ASSOCICANA).

\section{REFERENCES}

ALMEIDA, A. C.; SOUZA, J. L.; TEODORO, I.; BARBOSA, G. V. S.; MOURA, G.; FERREIRA, R. A. J. Desenvolvimento vegetativo e produção de cultivares de cana-de-açúcar em relação à disponibilidade hídrica e unidades térmicas. Ciência e Agrotecnologia, Lavras, v. 32, n. 5, p. 14411448, 2008.

AMBROSANO E. J.; TRIVELIN P. C. O.; CANTARELLA H.; AMBROSANO G. M. B.; SCHAMMASS E. A.; MURAOKA T.; ROSSI F. 15N-labeled nitrogen from green manure and ammonium sulfate utilization by the sugarcane ratoon. Scientia Agricola, Piracicaba, v.68, n.3, p.361-368, 2011.

BLUM, J.; HERPIN U.; MELFI, A. J.; MONTES, C. R. Soil properties in a sugarcane plantation after the application of treated sewage effluent and phosphogypsum in Brazil. Agricultural Water Management, Amsterdam, v. 115, n.0, p. 203 -216, 2012.

CARR, M. K. V.; KNOX, J. W. The relations and irrigation requirements of sugar cane (saccharum officinarum): a review. Experimental Agriculture, Cambridge, v.47, n.1, p.1-25, 2011.

CONSECANA, Manual de instruções. 5. ed. Piracicaba: Conselho dos Produtores de Cana-deAçúcar. Açúcar e Álcool do Estado de São Paulo, 2006. 111p.

COOK, F.J.; ORCHARD, V.A. Relationship between soil respiration and soil moisture. Soil Biology \& Biochemistry, Amsterdam, v.40, n.5, p.1013-1018, 2008.

DALRI, A. B.; CRUZ, R.L. Produtividade da cana-de-açúcar fertirrigada com N e K via gotejamento subsuperficial. Engenharia Agrícola, Jaboticabal, v.28, n.3, 2008.

FARIAS C. H. A.; FERNANDES P. D.; DANTAS NETO J.; GHEYI H. R. Eficiência no uso da água na cana-de-açúcar sob diferentes lâminas de irrigação e níveis de zinco no litoral paraibano. Engenharia Agrícola, v.28, n.3, Jaboticabal, p. 494-506, 2008.

FRANCO, H. C. J.; OTTO R.; FARONI C. E.; VITTI A. C.; OLIVEIRA E. C. A. DE, TRIVELIN P. C. O. Nitrogen in sugarcane derived from fertilizer under Brazilian field conditions. Field Crops Research, Amsterdam, v. 121, p. 29-41, 2011.

FRANCO, H. C. J.; TRIVELIN P. C. O.; FARONI C. E.; VITTI A. C.; OTTO R. Stalk yield and technological attributes of planted cane as related to nitrogen fertilization. Scientia Agricola, Piracicaba, v. 67, n. 5, p. 579-590, 2010.

GAVA, G. J. C. ; KÖLLN, O.T. ; URIBE, R.A.M. ; CANTARELLA, H. Interação entre água e nitrogênio na produtividade de cana-de-açúcar (Saccharum sp.). In: CRUSCIOL, C. A. C. (Org.). Tópicos em ecofisiolgia da cana-de-açúcar. Botucatu: FEPAF, 2010. v. 1, p. 49-66.

GAVA, G. J. C.; SILVA, M. A.; SILVA, R. C.; JERÔNIMO, E. M.; CRUZ, C. S.; KÖLLN, O.T. Produtividade de três cultivares de cana-de-açúcar sob manejos de sequeiro e irrigado por gotejamento. Revista Brasileira de Engenharia Agrícola e Ambiental, Campina Grande, v. 15, n.3, p. 250-255, 2011.

GONÇALVES, D. B. Considerações sobre a expansão recente da lavoura canavieira no Brasil. Informações Econômicas, São Paulo, v. 39, n.10, p.71-82, 2009.

MUCHOW, R. C.; ROBERTSON, M. J.; WOOD, A. W.; KEATING, B. A. Effect of nitrogen on the time-course of sucrose accumulation in sugar cane. Field Crops Research, Amsterdam, v.47, n. 2-3, p. 143-153, 1996. 
NG KEE KWONG, K. F,; DEVILLE, J. Application of ${ }^{15} \mathrm{~N}$-labelled urea to sugar cane through a drip-irrigation system in Mauritius. Fertilizer Research, Netherlands, v. 39, n. 3, p. 223-228 1994.

NG KEE KWONG, K. F.; PAUL, J. P.; DEVILLE, J. Drip-fertigation - a means for reducing fertilizer nitrogen to sugarcane. Experimental Agriculture, Cambridge, v. 35, n. 1, p. 31-37, 1999.

RAVIKUMAR V.; VIJAYAKUMAR G.; SIMUNEK J.; CHELLAMUTHU S.; SANTHI R.; APPAVU K. Evaluation of fertigation scheduling for sugarcane using a vadose zone flow and transport model. Agricultural Water Management, Amsterdam, v. 98, p. 1431-1440, 2011.

SILVA, A.B.; DANTAS NETO, J.; FARIAS, C.H. de A.; AZEVEDO, C.A.V. de. Rendimento e qualidade da cana-de-açúcar irrigada sob adubações de nitrogênio e potássio em cobertura. Revista Caatinga, Mossoró, v.22, n.3, p.236-241, 2009.

SILVA, M. A.; SILVA, J.A.G.; ENCISO, J.; SHARMA, V.; JIFON, J. Yield components as indicators of drought tolerance of sugarcane. Scientia Agricola, Piracicaba, v. 65, n. 6, p.620-627, 2008.

STUTTER M.I.; RICHARDS S.; DAWSON J.J.C. Biodegradability of natural dissolved organic matter collected from a UK moorland stream. Water Research, London, v. 47, p. 1169 - 1180, 2013.

THORBURN, P. J.; DART, I. K.; BIGGS, I. M.; BAILLIE, C. P.; SMITH, M. A.; KEATING, B. A. The fate of nitrogen applied to sugarcane by trickle irrigation. Irrigation Science, Berlin,v. 22, n. 3-4, p. 201-209, 2003.

WIEDENFELD. R. P. Water stress during different sugarcane growth periods om yield and response to N fertilization. Agricultural Water Management, v. 43, p. 173-182, 2000.

WIEDENFELD, R. P. Effects of irrigation and N fertilizer application on sugarcane yield and quality. Field Crops Research, Amsterdam, v.43, n. 2-3, p. 101, 1995.

WIEDENFELD. B.; ENCISO, J. Sugarcane responses to irrigation and nitrogen in semiarid south texas. Agronomy Journal, Madison, v. 100, n.3, p. 665-671, 2008. 